\title{
Linking Histone Methylation to Active DNA Demethylation
}

\section{Tamer Fandy*}

Department of Pharmaceutical Sciences, Albany College of Pharmacy, USA

The role of epigenetic modifications in regulating gene expression and disease progression is continuously evolving with the vast increase in our knowledge about these modifications and their physiological function. The histone code hypothesis initially proposed by Strahl and Allis [1] indicated that different combinations of covalent histone modifications influence chromatin structure and the output of the transcription machinery. The hypothesis was further extended to link the distinct histone combinations to physiological processes like apoptosis and the description of the apoptotic histone code [2]. Histone acetylation by histone acetyltransferase (HAT) and deacetylation by histone deacetylases (HDAC) are considered the most studied histone modifications and had been the focus of intense investigation in the last two decades. Those efforts were acclaimed by the FDA approval of the HDAC inhibitors vorinostat and romidepsin for the treatment of Cutaneous T Cell Lymphoma (CTCL).The link between histone acetylation and other epigenetic modifications like DNA methylation was unclear until Bird and others [3,4] described the recruitment of HDAC repressor complex by methyl-CpG-binding proteinsto methylated cytosines on DNA. The concept of hierarchical organization of histone acetylation and DNA methylation was proposed later on and speculated that DNA methylation is dominant over histone acetylation $[5,6]$. Emerging clinical trials using the combination of HDAC inhibitors and DNA methyltransferase (DNMT) inhibitors embraced that concept and adopted a sequential approach of administration starting with DNMT inhibitor followed by HDAC inhibitor $[7,8]$.

Histone lysine methylation is another histone modification that can regulatethe DNA methylation machinery. Histone lysine methylation is a dynamic process regulated by histone lysine methyltransferases (KMTs) and demethylases (KDMs) and plays an important role in tumor progression. Epigenetic readers like the inhibitor of growth protein 1 (ING1) recognize histone trimethylation on a specific lysine residue (H3K4) [9]. The ING family (ING1-5) has been an emerging putative tumor suppressor gene that binds to histones in a methylationsensitive manner through a conserved Plant Homeodomain (PHD). Recently, the role of ING1 as an adaptor for the DNA demethylation machinery was identified [10]. ING1 binding to trimethylated H3K4 recruits the growth arrest and DNA Damage protein 45a (Gadd45a). Gadd45a induces gene-specific DNA demethylation through several steps that include deamination of methylated cytosine by ActivationInduced Deaminase (AID) enzyme followed by base excision repair using the thymine DNA glycosylase MBD4 [11].

Based on such findings, it is tempting to hypothesize that the combination of lysine-specific demethylase inhibitor with DNMT inhibitor would potentiate the DNA demethylation activity of the latter and enhance the re-expression of epigenetically silenced genes. Lysine-Specific Demethylase1 (LSD1) suppresses gene expression by demethylatingmono-and dimethyl-H3K4 histone marks that are associated with active gene expression. $\mathrm{KDM} 5 \mathrm{C} / \mathrm{Jarid} 1 \mathrm{C}$ is another transcriptional repressor lysine-specific demethylase that acts on trimethylated and dimethylated $\mathrm{H} 3 \mathrm{~K} 4$. Inhibitors of LSD1 and KDM5C could potentiate the induction of silenced genes by DNMT inhibitors. Indeed, LSD1 inhibitors as single agents were successful in re-expressing epigenetically silenced genes like $C D H 1$ in leukemia cells and augmented apoptosis induction when combined with HDAC inhibitors in glioblastoma cells $[12,13]$. Although such combination suffers the common disadvantage of epigenetic agents; induction of global changes in histone and DNA methylation with consequent nonspecific gene expression changes, it may constitute a successful combination therapy for different types of cancer.

\section{References}

1. Strahl BD, Allis CD (2000) The language of covalent histone modifications. Nature 403: 41-45.

2. Füllgrabe J, Hajji N, Joseph B (2010) Cracking the death code: apoptosisrelated histone modifications. Cell Death Differ 17: 1238-1243.

3. Bird AP, Wolffe AP (1999) Methylation-induced repression--belts, braces, and chromatin. Cell 99: 451-454.

4. Knoepfler PS, Eisenman RN (1999) Sin meets NuRD and other tails of repression. Cell 99: 447-450.

5. Cameron EE, Bachman KE, Myöhänen S, Herman JG, Baylin SB (1999) Synergy of demethylation and histone deacetylase inhibition in the reexpression of genes silenced in cancer. Nat Genet 21: 103-107.

6. Jones PA, Baylin SB (2002) The fundamental role of epigenetic events in cancer. Nat Rev Genet 3: 415-428.

7. Gore SD, Baylin S, Sugar E, Carraway H, Miller CB, et al. (2006) Combined DNA methyltransferase and histone deacetylase inhibition in the treatment of myeloid neoplasms. Cancer Res 66: 6361-6369.

8. Fandy TE, Herman JG, Kerns P, Jiemjit A, Sugar EA, et al. (2009) Early epigenetic changes and DNA damage do not predict clinical response in an overlapping schedule of 5-azacytidine and entinostat in patients with myeloid malignancies. Blood 114: 2764-2773.

9. Peña PV, Hom RA, Hung T, Lin H, Kuo AJ, et al. (2008) Histone H3K4me3 binding is required for the DNA repair and apoptotic activities of ING1 tumor suppressor. J MolBiol 380: 303-312.

10. Schäfer A, Karaulanov E, Stapf U, Döderlein G, Niehrs C (2013) Ing1 functions in DNA demethylation by directing Gadd45a to H3K4me3. Genes Dev 27: 261. 273.

11. Rai K, Huggins IJ, James SR, Karpf AR, Jones DA, et al. (2008) DNA demethylation in zebrafish involves the coupling of a deaminase, a glycosylase, and gadd45. Cell 135: 1201-1212

12. Murray-Stewart T, Woster PM, Casero RA Jr (2013) The re-expression of the epigenetically silenced e-cadherin gene by a polyamine analogue lysinespecific demethylase-1 (LSD1) inhibitor in human acute myeloid leukemia cell lines. Amino Acids

13. Singh MM, Manton CA, Bhat KP, Tsai WW, Aldape K, et al. (2011) Inhibition of LSD1 sensitizes glioblastoma cells to histone deacetylase inhibitors. NeuroOncol 13: 894-903.

*Corresponding author: Tamer Fandy, Department of Pharmaceutical Sciences, Albany College of Pharmacy 261 Mountain View Rd, Colchester, VT 05446, USA Tel: 802-735-2634; Fax: 802-654-0716; E-mail: Tamer.Fandy@acphs.edu

Received June 11, 2013; Accepted June 11, 2013; Published June 15, 2013

Citation: Fandy T (2013) Linking Histone Methylation to Active DNA Demethylation. J Pharmacogenom Pharmacoproteomics 4: e133. doi:10.4172/2153-0645.1000e133

Copyright: (c) 2013 Fandy T. This is an open-access article distributed under the terms of the Creative Commons Attribution License, which permits unrestricted use, distribution, and reproduction in any medium, provided the original author and source are credited. 